\title{
Teaching and Learning from Journal Feedback: A Reflective Study
}

\author{
Adventor M. Trye, Jr., PhD \\ Adventist University of West Africa, Liberia \\ ${ }^{*}$ Corresponding Mail: tryejr@auwa.edu.Ir
}

\begin{abstract}
Reflective journal writing and giving timely feedback is one of the effective teaching strategies used in the academia. This article highlights some of the responses of the students from a course taught thrice by the author at a faith-based university in Liberia from September 2017 to August 2018. While the first class had 109 students, the second had 68 students and the third had 86 students. At the end of every class, students were asked to answer the following questions (a) what did you learn in today's class? (b) What went well in today's class? (c) What could be improved from today's class? The last one (d) was do you have any questions or comments for your teacher? Based on personal experiences and reactions from the students, both the teacher and the students learned from the journal writing and the rapid feedback experiences provided before the teacher proceeded to a new topic. The author discovered that journal writing was student-centered which served as an evaluation tool for the teacher. It was used for students' attendance and it motivated the teacher as well. Although journal writing was time consuming for teaching larger classes, it was rewarding because both the teacher and the students learned from the journal feedback experience. The author recommends journal writing because it enhances the teaching and learning process.
\end{abstract}

Keywords: Classroom faith-based, feedback, higher education, instructional strategy, journal writing.

\section{Introduction}

Teachers are constantly in the business of influencing their students' thinking. When it comes to promoting quality education, critical thinking is imperative. Critical thinking is defined as a teaching process whereby the teacher influences students to think and make connections from lessons learned in the classrooms and laboratories (Green and Henriquez- Green, 2008, Trye, 2017). The practice of journal writing and providing feedback in the classroom promotes critical thinking because the students are able to reflect on the lessons taught by their teacher and make reactions that will eventually reveal whether effective learning has taken place or not.

Generally, literature shows that feedback fosters interaction and has both negative and positive influences on students' learning and achievement (Hattie \& Timperly, 2007). Furthermore, the authors emphasize that effective feedback is meant to answer the following set of questions:

1. Where am I going or what are the goals?

2. How am I going or what progress is being made toward the goal?
3. What activities need to be undertaken to make better progress?

In responses to these questions, Hattie and Timperly $(2007$, p. 86) further argued that effective feedback focuses on four levels: feedback about the task, feedback about the processing of the task, feedback about self-regulation and feedback about the self as person. They believed that feedback about self as a person is the least form of feedback because this focus ignores the task given by simply focusing on the person doing the task.

Specifically, journal feedback as a practice in the field of education is used "to structure the environment so that communication flows smoothly between teachers and participants" (Green and Henriquez-Green, 2008, p. 47). Furthermore, the authors suggested the following three aspects for journaling: what went well in the lesson, what could be done to improve the lesson and questions or comments for improvement. The author of this article suggests one more aspect regarding expression of what the learners have learned from a particular instruction. 
To sum up, the literature on feedback and journal writing mentioned journal writing as a useful educational practice because it "helps produce a healthier and more productive learning environment (Green and Henriquez- Green, 2008, p. 47). The participants' responses to the journal questions enable the teacher to influence the students' thinking. Adjustments are therefore made to foster quality education.

\section{Methodology}

This paper employed a qualitative action research design. The methodological section is divided into four parts: the meaning of action research, the stages of action research, purposes of action research and sampling procedures.

\section{Action Research Defined}

Kurt Lewin was the leading proponent of action research. Born in 1890 to a Jewish middle class family, Lewin was increasingly interested in the concept of Jewish migration and identity. In 1944, when Lewin was a professor at the Massachusetts Institute of Technology (MIT), he coined the term "action research" (Mills, 2003; Stringe, 2004; Taylor, Wilkie and Baser, 2000).

Ever since Lewin coined the term action research, practitioners and researchers have called it by a variety of names. Some of the names that are synonymous with action research are participatory research, collaborative inquiry, emancipatory research, action learning and contextual action research (O'Brien, 1998). Action research can also be applied in programs or educational techniques that are not necessarily experiencing any problems but that educators simply want to learn more about and improve (Hidden Curriculum, 2014).

Action research is simply "learning by doing"-a qualitative type of inquiry whereby a group of people identify a problem, do something to resolve it, see how successful their efforts were and if not satisfied try again (O'Brien, 1998). Hence, action research is a reflective study derived from the researcher's experience. Similarly, Mills (2003) mentioned that action research is "any systematic inquiry conducted by teacher researchers, principals, school counselors or other stakeholders in the teaching/ learning environment to gather information about how their particular schools operate, how they teach and how well their students learn"( p. 5). Sagor (2000) also argues that action research is an inquiry that is primarily conducted to assist the actor in improving and /or refining his or her action. Action research is relevant to the participants and the researcher as well.

\section{Purposes of Action Research}

Action research is not a library research where the researcher is required to sit in the library to complete all the stages. Usually, action researchers aim at accomplishing three main goals: building the reflective practitioner, making progress on school wide priorities and building professional cultures (Ferrance, 2000). According to Sagor (2000), the primary purpose of action research is to inform the decision making of practitioners who wish to improve their performance. This paper is a reflective study that highlights the author's experiences of what transpired in the classroom at a faith-based university. The focus of this paper was on journaling. It was one of the best classroom practices employed by the author of this article. The author of this study employed journal writing in the classroom for three academic semesters.

\section{Stages of the Action Research}

Since 1946, Lewin's set of procedures for action research continues to be adhered to by educational researchers (Mills, 2003; Stringe, 2004; Taylor, Wilkie and Baser, 2006). For instance, Lewin's spiral steps have to do with reflection, planning, acting, observation and reflection. Sagor (2000) believed that action research has the following seven stages: selecting a focus, clarifying theories, Identifying research questions, collecting data, analyzing data, reporting results and, taking informed action.

Selecting a focus is the first stage of action research. In this stage, a significant investment of time and energy is employed by the researcher by doing reflective journal writing, interviews and analysis. When it comes to clarifying theories, this step involves making explicit one's underlying feelings, beliefs and insights regarding the problem or focus (Sagor, 2000). In other words, the action researcher can state his bias in this section. Literature review can be done in this step for the express purpose of identifying and clarifying key concepts of the study.

The third step is identifying of research questions. In this stage, the action researcher is concerned with the following questions: what significant aspect(s) of the theory is one relatively uncertain about and therefore wishes or needs to know more about (Sagor $(2000$, p. 17). The fourth stage is the data collection whereby the researcher needs to come up with data from the participants. The fifth step is the data analysis which asks two significant questions: 
(a) what is the story told by the data? (b) What might explain this story? (p. 20). The sixth and seventh steps of action research deal with the reporting and action taking. At these stages, the researcher might have gathered results necessary for improvement.

\section{Sampling}

Purposive sampling method was used to select the responses of students who attended the course taught thrice by the author of this paper. While the first class had 109 students, the second had 68 students and the third had 86 students. At the end of every class, all the students' journal papers were read and graded. The feedback was presented in the next class right after the devotional. Thematic approach was used to organize the feedback from students and present them accordingly.

\section{Students' Responses}

At the end of every class, students were asked to give brief responses to the following sets of questions: (a) what went well or what have you learned? (b) What could be improved from today's class? (c) Any questions or comments to the teacher? After they had written their responses, the teacher summarized the responses and read them during the next class sessions.

The first set of questions asked was, what went well or what did you learn from today's class? Students' responses to the question regarding what went well varied. Their responses included the (a) dress code of the teacher, (b) teacher's presentation of the lesson, (c) punctuality of the teacher, (d) learning and singing of new songs, (e) questions and answers during the journal feedback, (g) the devotional talks and $(f)$ the motivational talks. Between September and December 2017, when the author of this article taught for the first time at the institution, it was observed that students' answers had little to do with what they learned. Some of the students' answers did not relate to the lesson of the day, rather their attention were on the teacher's behavior during the lesson presentation. For instance, some of the students said, "one of the things that went well in today's class was the dress code of the teacher" (Students' Journal, 2017 and 2018). "I like your voice, I like your smile" (Students' Journal, 2017 and 2018).

While some of the students focused on the teacher, on the other hand, some students did not give specific answers to the question. One of the general responses that kept coming was, "everything went well in today's class" (Students' Journal, 2017 and 2018). Being unsatisfied with such responses, when the course was taught for the second semesterJanuary to April 2018, the researcher decided to concentrate on the question which says, what did you learn from today's class.

By asking such a question to the students, the teacher was technically encouraging the students to mention at least one or two things they remembered from the lesson. The students' responses to this question proved much better compared to the previous questions which provided responses that were nonspecific. Therefore, one of the lessons that the researcher learned was, when the teacher askes the right question in the journal, the students give answers that are more satisfactory to the teacher.

Another question was what could be improved from today's class? At the end of every class, the students mentioned areas that did not go well during the lesson presentations. The complains of the students included (a) distraction from classmates, (b) bad weather, (c) lack of conducive classroom environment, (d) large population of students in the classroom, (e) the teacher did not answer my question properly ( $f$ ) the teacher did not recognize my hand, (g) today's class was not exciting, (h) the reading of today's journal was too long, (i) the PowerPoint presentation was not clear, and (j) your teaching was too fast (Students' Journal, 2017 and 2018). These negative comments from students challenged and motivated the teacher to perform better in subsequent classes.

Lastly, the students were asked to answer- any questions or comments for the teacher. This last question generated several comments. While some students wrote questions regarding things that were related to the topic of the day, other students wrote questions that were personal as well as comments that were about the teacher's teaching method. It was observed that during the first few weeks of class, the students wanted to know why they were asked to write a journal. They further wanted to know how many points they would obtain for journal writing.

On the last day of class, some students wrote personal letters appreciating the impact of journaling on their learning. One of the students said, "Dr. Trye, thanks for the time you spent with us from the beginning of this semester to the end. You really did your best, keep it up and God will 
surely reward you" (Student's Journal, December, 2017). Another student wrote, "Thanks for the knowledge gained from you about the Life and Teaching of Christ course. From your teaching, have learned many things about our Lord and Savior Jesus Christ including His birth, baptism and His ministry on earth (Student's Journal, December, 2017). Another student said, "Well, this is one of my best classes and a wonderful lecturer I have ever met throughout my schooling" (Student's Journal, April 17, 2018).

Similarly, another student wrote, "You are such an organized person. Thank you for the wonderful time you spent teaching us" (Student's Journal, April, 2018). The last feedback went like this:

If at the end of the class the least student in the class is able to write what they have been taught for over an hour, then that teacher is great. This is because the goal of teaching is for the least in the class to be able to grasp a word after that period. You came to impart, not to make students inferior. So, Bravo Mr. Trye, well done. You were the best (Student's Journal, April, 2018).

After reading the comments from the students, the researcher reflected on the positive and negative responses which helped to improve the next teaching and learning session.

\section{Conclusions and Recommendations}

The practice of journal writing is one of the many student centered teaching and learning strategies which can be employed by educators in the classroom.Based on the author's experience, the practice of journal writing and the giving of immediate feedback in the classes was rewarding because both the teacher and the students learned from the process. Upon employing the practice of journaling for three academic semesters, the author of this article learned the following about journal writing and feedback:

Journal writing by students and the teachers' provision of rapid feedback fostered the interaction between the teacher and the students. Journal writing served as an evaluation tool for the teacher because the teacher used the students comments to daily improve on his teaching techniques, methodologies and strategies.

Journal writing was used to improve the students' attendance because the teacher graded the students' feedback and therefore it was necessary for them to attend and participate.

Journal writing and the provision of rapid feedback further motivated the teacher to be more creative. The feedback, though, was time consuming for teaching the larger class because the teacher sacrificed ample time in grading the papers and providing feedback to the students. However, journaling was rewarding because the students expressed that effective learning has taken place. Students were often excited to hear what others wrote in their journal.

Based on the lessons learned from this reflective study, the author recommends that teachers should employ such instructional strategies as journal writing for maximized learning effectiveness. Finally, further studies should be done on the impact of journal writing at high school level of study.

\section{Reference}

Green, W., \& Henriquez- Green, R. (2008). Basic moves of teaching: Building on cooperative learning. Victoria, BC: Trafford.

Ferrance, E. (2000). Retrieved from http://www.brown.edu/academics/educati on-alliance/sites/brown. edu.acade mics. education-alliance/files/pu blication s/act_ research.pdf

Green, W., \& Henriquez- Green, R. (2008). Basic moves of teaching: Building on cooperative learning. Victoria, BC: Trafford.

Hattie, J., \& Timperley, H. (2007) The Power of Feedback, in Review of Educational Research, Vol.77, No. 1, nol. Pp. 81-11. DOI: 10.3102/003465430298487.

Hidden curriculum (2014, A. 2.-c. (n.d.). The Glossary of Education Reform. Retrieved from http://edglossary.org/action-research/ http://www.brown.edu/academics/educati on-alliance/sites/brown.edu.academics .edu cat ion alliance/files/publications/act_re sear ch.pdf. (n.d.).

Mills, E. G. (2003) Action Research: A guide for the teacher researcher. Upper saddle River, New Jersey: Merrill Prentice Hall.

O'Brien, R. (1998). An Overview of the Methodological Approach of Action Research. Retrieved January 1, 2002, from 
http://web.net/robrien/papers/arfinal. html.

Stringe, E. (2004). Action Research in Education. Upper Saddle River, New Jersey: Pearson Prentice Hall.

Sagor, R. (2000). Guiding School Improvement with Action Research. Association for Supervision and Curriculum Development Alexandria, Virginia USA.
Taylor, C., Wilkie, M.,\& Baser, J. (2006). Doing Action Research: A guide for school support staff. London: Paul Chapman.

Trye, Jr., A. M. (2017). An appreciative inquiry of the integration of faith and learning practices in Adventist higher educational institutions in Southeast Asia. Doctoral Dissertation. AllAS, Philippines. 